\title{
PROTEOMICS OF CHONDROGENESIS: A REVIEW
}

\author{
Tay $L X$ \\ Faculty of Medicine, University of Malaya, Kuala Lumpur
}

\section{Correspondence:}

Tay Liang Xin

Tissue Engineering Group (TEG), National Orthopaedic Center of Excellence for Research and Learning (NOCERAL), Department of Orthopaedic Surgery, Faculty of Medicine, University of Malaya, 50603 Kuala Lumpur

Email: liangxin28@gmail.com

Phone no.: 603-79677543

Fax: 03-79494642

\begin{abstract}
Osteoarthritis (OA) affects millions of people worldwide with its irreversible destruction of articular cartilage. Recently, the potential of using chondrogenic differentiated multipotent mesenchymal stromal cells (cMSCs) for OA treatment is being assessed. Preliminary clinical studies have been encouraging. However current studies have also demonstrated that cMSCs are not biochemically and biomechanically identical to native articular chondrocytes (ACs). Thus, there is an urgent need for the implementation of proteomic applications as proteomics involve protein identification, relative quantification of proteins and studies of post-translational modification which reveal novel regulating processes of complex mechanisms such as in chondrogenesis. A comprehensive understanding of chondrogenesis is essential for the establishment of an effective cMSC model to regenerate cartilage. In this article, we will review current proteomic studies on chondrogenesis, focusing on recent findings and the proteomic approaches utilised.
\end{abstract}

Keywords: Chondrocyte, chondrogenesis, proteomic, MSC

\section{Introduction}

Due to the limited intrinsic regenerative capacity of articular cartilage, minor tissue injuries may lead to the development of osteoarthritis (OA), a musculoskeletal disease commonly found in the elderly $(1,2)$. Recent advances in regenerative medicine have demonstrated that tissue engineering-based constructs enhanced the healing of articular cartilage (3). Using both conventional and sophisticated proteomic approaches, chondrogenic differentiated mesenchymal stromal cell (cMSC) constructs were characterized and conformed to the expression of the chondrogenic phenotype. Several recent studies have shown that although cMSCs expressed the chondrogenic phenotype, a portion of the gene and the protein expression were found deviated from the native articular chondrocytes (ACs) (4, 5). These cells were also biochemically and biomechanically inferior when compared to the native ACs (6-9). Hence, there is a need to develop an effective in vivo model to induce and sustain the chondrogenic differentiation of the multipotent mesenchymal stromal cells (MSCs). Before an advance in this area can be achieved, it is essential to have an understanding of the fundamental processes of, and the recent findings in, chondrogenesis. Proteomic aspects of MSC have been described $(10-12)$. Thus, this review aims to further update readers on the latest findings of proteomics in chondrogenesis.

\section{Chondrogenesis}

Chondrogenesis is a complex process which is directed by a highly regulated consortium of growth factors and signalling molecules. It goes through three stages: an initial condensation of cells which is characterized by $\mathrm{N}$-cadherin; followed by a differentiation characterized by collagen II; and a final terminal differentiation characterized by collagen $X$ (13-15). cMSC expressed a wide range of chondrogenesis related genes including the genes for the SRY (sex determining region Y-box) SOX 5, 6 and 9, type II collagen and aggrecan and secreted a cartilaginous extracellular matrix similar to $A C(16,17)$. It has demonstrated a potential to replace AC for clinical therapies in the future. In the past, numerous studies focused on the mechanism of chondrogenesis and its signalling pathways $(16,18-20)$. In the first clinical case where human MSCs were implanted into osteochondral defects, the formation of some cartilage-like tissue was noted $(21,22)$. However, expanding the micro-scale cartilage formation from in vitro to large-scale cartilage tissue engineering still remains a challenge in regenerative medicine.

The advances in technology have allowed more detailed studies to be performed, such as a quantitative evaluation of protein expression at different stages of chondrogenesis, the discovery of new functional proteins involved in the 
chondrogenesis pathway as well as the measurement of its cellular mechanical properties $(6,9,23,24)$. These studies demonstrated that CMSC and AC have similar chondrogenic phenotypic expression, but the level of similarity at the molecular aspect remained unresolved (6-9). To illustrate this point, Table 1 summarizes these differences between cMSC and AC in terms of the cellular morphology and the molecular and biomechanical properties.
As listed in Table 1, a portion of cMSC genes was expressed differently compared to the $\mathrm{AC}$ gene. These differences in gene expression and the morphology and biomechanical properties of $\mathrm{CMSC}$ and $\mathrm{AC}$ provide evidence that research is needed to determine if these differences are caused by protein expression. Proteins represent the fundamental functional molecules within a cell and they contribute to the mechanical properties of the tissue

Table 1: Evaluation of the molecular, morphological and biomechanical properties between cMSC and AC. (References: $6,7,8,9,23$ \& 24)

\begin{tabular}{lll}
\hline & cMSC & AC \\
\hline Surface topology & $\begin{array}{l}\text { Spherical but flatter with a central hump of } \\
\text { condensed mass and a surrounding thin and } \\
\text { broad pleat }\end{array}$ & Spherical \\
\hline $\begin{array}{l}\text { Compressive equilibrium } \\
\text { modulus }\end{array}$ & $\begin{array}{l}75-114 \mathrm{kPa} \\
\text { Reached plateau at day 28 }\end{array}$ & $180-240 \mathrm{kPa}$ \\
\hline Dynamic modulus & $700-1100 \mathrm{kPa}$ & Reached plateau at day 42 \\
\hline Adhesion force & $4.54 \mathrm{nN}$ & $1000-1400 \mathrm{kPa}$ \\
\hline Surface stiffness & $0.109 \mathrm{~N} / \mathrm{m}$ & $6.86 \mathrm{nN}$ \\
\hline Gene expression & 324 genes mis-expressed during chondrogenesis & \\
\hline
\end{tabular}

Under expressed genes:

Proteoglycan 4, Similar to MAGEL2

protein, CXCL14, Dickkopf-1, Periostin,

ID1, Chondromodulin, TGF-beta induced

68kDa protein (TGFB1), Hox4A, SOSTDC1,

Thrombospondin 4, Epithelial V-like Antigen 1,

Proteoglycan 4, Similar to Protocadherin 10,

Calpain 6, helix-loop-helix transcription factors-

HES1, HES5

Over expressed genes:

Aggrecan, type II, IX and XI collagen, Similar to leiomodin1, Caspase 4, Meis homeobox 2, Fas, ID1

Protein expression No parathyroid hormone-related protein
expression

Expressed parathyroid
hormone-related protein

Higher protein expression:

type II collagen, integrin-1,

cMSC chondrogenic differentiated mesenchymal stromal cell; AC articular chondrocyte

(25). Characterization of the cMSC proteome would be informative and worth investigating, as it reflects the actual expression of proteins encoded by a specific gene.
In addition, the post-transcriptional regulation processes of protein amount, stability, subcellular localization, post-translational modifications and protein-protein 
interactions can only be elucidated at the proteome level (26). Therefore, the importance of proteome analysis of cMSC can never be emphasized enough.

\section{Proteomic Findings on Chondrogenesis}

7 significant proteomic related studies on chondrogenesis were identified through a literature search in a ten year period, from 2004 to 2013. The details of these studies are summarized in Table 2. Various proteomic approaches were utilised; the advanced non-gel based technique, two-dimensional (2D) online liquid chromatography tandem mass spectrometry (on line LC-MS/MS) and the conventional two-dimensional electrophoresis (2-DE) gel based methods.

The first cMSC proteomic study used a two dimensional electrophoresis coupled with mass spectrometry ( 2- DE LC $\mathrm{MS} / \mathrm{MS}$ ) to detect the altered proteins due to transforming growth factor b (TGF-b) (27). Human bone marrow derived mesenchymal stromal cells (hbmMSC) cultured in a transforming growth factor (TGF) -b medium led to the identification of 30 altered proteins. The altered proteins consisted of cytoskeleton proteins (16\%), cell membrane proteins $(9 \%)$, ECM proteins (12\%), metabolic enzymes (29\%), protein synthesis and degradation proteins (9\%) and stress response proteins (25\%) (27) .

In another study which utilized a similar two-dimensional electrophoresis (2-DE) and mass spectrometry, four chondrogenic differentiated proteins were identified (28). Interestingly, only collagen alpha 1 (II) chain precursor protein was identified in both studies, while the remaining proteins, vascular cell adhesion protein-1 precursor (V-CAM), GTP binding protein RAD and leukaemia inhibitory factor precursor (LIF) cholin were found in the latter study only (28).

In a study using differential gel electrophoresis (DiGE) and umbilical cord stromal derived MSC (ucMSC), De la Fuente et. al. identified 39 modulated proteins during chondrogenesis over a forty six day period of the study. With the 2D-DiGE approach 3 protein samples labelled with different fluorescent dyes could be loaded together in one single gel and this allowed for quantitative comparative analyses of all the samples in a single gel with a significant reduction of inter-gel variability. Proteins of the major cell functions of cellular differentiation, proliferation and migration were detected (23). Some of the up-regulated proteins were procollagen-lysine (PLOD2), enolase (ENO1), heat shock protein beta-1 ( HSPB1), superoxide dismutase ( SOD) and zyxin (ZYX) while down-regulated proteins were calreticulin ( CRT), vimentin ( VIM) and protein disulfideisomerase (PDI) (Table 3 and Table 4).

Ji et. al. applied a gel free isobaric tag for relative and absolute quantitation (iTRAQ) labeling coupled with 2D LC/ $\mathrm{MS} / \mathrm{MS}$ proteomics technology to quantitate the protein expression profile of an in vitro chondrogenic model for six days. In this study, the authors used a murine embryonic mesenchymal cell line, C3H10T1/2. Identified up-regulated proteins were mainly enzymes involved in cartilage extracellular matrix (ECM) synthesis and mature chondrocytes whereas down-regulated proteins were predominantly involved in energy metabolism, chromatin organization, transcription, mRNA processing, signaling transduction and cytoskeleton (Table 3 and Table 4) (24).

Using the technology of stable isotope labelling with amino acids in cell culture (SILAC), Rocha et. al. analyzed the cell lysate of a micromass pellet culture at day 2 and day 14 in order to evaluate the protein changes at an advanced differentiation stage (29). hbmMSC were grown in a culture medium supplemented with isotope-labelled amino acids, lysine (Lys) and arginine (Arg). The cells were harvested at designated days and subsequently analyzed with mass spectrometry. Majority of the identified upregulated proteins were related to cellular metabolism and the glycolytic pathway. Others were involved in protein synthesis and turnover, cytoskeleton organization and chaperones/stress response (Table 3). Some of these proteins were also detected using 2D-DiGE and ITRAQ approach in other chondrogenesis models $(23,24)$. The reproducibility of the results demonstrated that SILAC could serve as an alternative method for quantitative proteomic studies in the future.

\section{Glycoproteomics}

Ishihara et. al. utilized a novel glycoform-focused reverse proteomic method to study chondrogenesis (30). Glycoproteomics is a recent proteomic approach which characterizes plasma membrane proteins (31). The investigators performed glycoblotting coupled with highthroughput matrix assisted laser desorption/ionization (MALDI) - time of flight (TOF) mass spectrometry for comprehensive analyses of altered $\mathrm{N}$-glycans on ATDC5 cells during chondrogenesis. The identified major components were high-mannose type $\mathrm{N}$-glycans which have essential roles in the homeostatic and functional maintenance of the chondrocyte $(32,33)$. From the 245 identified glycoproteins, five cell surface glycoproteins, collagen alpha-1 (III) chain, collagen alpha-1 (XI) chain, ectonucleotide pyrophosphatase/phosphodiesterase family member 1 , aquaporin-1 and netrin receptor (UNC5B) were proposed as candidates for chondrogenic differentiation markers and as pharmaceutical targets in OA (Table 3) (30).

\section{Transplantation Proteomics}

After stem cell therapy, proteomic analyses of the tissues and body fluids should be performed to address the safety and feasibility of stem cell therapy. Gong et. al. (34) performed an in vivo quantitative analysis on the transplanted porcine articular cartilage with native cartilage tissue. This led to the identification of a large number of differentially expressed proteins. Among the identified proteins, 43 proteins in the post - transplantation cartilage tissue exhibited significant quantitative differences from the native tissue (34). These proteins were categorized into four functional groups; glycolysis, cellular organization, signaling pathway and others (Table 3 and Table 4). These 
results concurred with previous studies that showed that regenerated cartilage tissue were not identical to native tissue. The identification of these proteins will provide chemical and mechanical clues to improve the quality of engineered cartilage tissues.

\section{Findings of Proteomic Studies}

Each of these techniques possesses intrinsic advantages and limitations (35-37). Despite the short-comings, proteomic approaches have revealed many novel cartilageand OA-related proteins. These identified proteins, are upor down-regulated during chondrogenesis. These proteins can be categorized according to their proposed functional roles: ECM and cytoskeleton related protein, metabolic enzymes, protein of synthesis and degradation, chaperones and stress related proteins and others and are presented in Tables 3 and 4. ( Ref 23, 24, 27, 28, 29, 30, \& 34)

Table 2: Summary of the proteomic findings from published chondrogenesis papers

\begin{tabular}{|c|c|c|c|c|c|c|c|c|c|}
\hline \multirow{2}{*}{$\begin{array}{l}\text { Cell } \\
\text { type/ } \\
\text { source }\end{array}$} & \multirow[b]{2}{*}{ Cell Line } & \multirow{2}{*}{$\begin{array}{l}\text { Passage/ } \\
\text { Culture type }\end{array}$} & \multirow{2}{*}{$\begin{array}{l}\text { Treatment/ } \\
\text { Duration }\end{array}$} & \multirow{2}{*}{$\begin{array}{l}\text { Proteomic } \\
\text { approach }\end{array}$} & \multicolumn{2}{|c|}{$\begin{array}{l}\text { Identified } \\
\text { proteins }\end{array}$} & \multirow{2}{*}{$\begin{array}{l}\text { Differentially } \\
\text { expressed } \\
\text { proteins }\end{array}$} & \multirow[t]{2}{*}{ Major result } & \multirow[t]{2}{*}{ Ref. } \\
\hline & & & & & Total & Unique & & & \\
\hline $\begin{array}{l}\text { hBM- } \\
\text { MSCs }\end{array}$ & NA & $\begin{array}{l}\text { P10, } \\
\text { monolayer }\end{array}$ & $\begin{array}{l}10 \mathrm{ng} / \mathrm{mL} \\
\text { TGF-b1 } \\
4 \text { days }\end{array}$ & $\begin{array}{l}\text { 2-DE/LC- } \\
\text { MS/MS }\end{array}$ & 1500 & 1 & 30 & $\begin{array}{l}\text { The increase } \\
\text { of a-actin and } \\
\text { the decrease of } \\
\text { gelsolin promotes } \\
\text { chondrogenesis }\end{array}$ & (27) \\
\hline mEMCs & С3Н10T1/2 & $\begin{array}{l}\text { ND, } \\
\text { micromass }\end{array}$ & $\begin{array}{l}100 \mathrm{ng} / \mathrm{mL} \\
\mathrm{hBMP}-2 \\
6 \text { days }\end{array}$ & $\begin{array}{l}\text { iTRAQ/2D } \\
\text { nanoLC/ } \\
\text { MS/ MS }\end{array}$ & 1753 & 100 & 100 & $\begin{array}{l}\text { Biological roles } \\
\text { of BTF314 and } \\
\text { fibulin-5 were } \\
\text { identified and } \\
\text { verified involving in } \\
\text { chondrogenesis. }\end{array}$ & (24) \\
\hline $\begin{array}{l}\text { hBM- } \\
\text { MSCs }\end{array}$ & NA & $\begin{array}{l}\text { ND, } \\
\text { micromass }\end{array}$ & $\begin{array}{l}\text { NA, } 2 \text { and } \\
14 \text { days }\end{array}$ & $\begin{array}{l}\text { SILAC/ } \\
\text { LC-MALDI- } \\
\text { TOF/TOF }\end{array}$ & 622 & 65 & 65 & $\begin{array}{l}\text { Fibronectin, } \\
\text { gelsolin, vimentin, } \\
\text { alpha-ATPase, } \\
\text { mitochondrial } \\
\text { superoxide } \\
\text { dismutase and } \\
\text { cyclophilin A were } \\
\text { up-regulated in } \\
\text { chondrogenesis. }\end{array}$ & (29) \\
\hline $\begin{array}{l}\text { rBM- } \\
\text { MSCs }\end{array}$ & NA & $\begin{array}{l}\text { P2, } \\
\text { monolayer }\end{array}$ & $\begin{array}{l}5 \mathrm{ng} / \mathrm{mL} \\
\text { TGF-b1, 0, } \\
7,21 \text { and } 28 \\
\text { days }\end{array}$ & $\begin{array}{l}\text { 2-DE/ } \\
\text { MALDI- } \\
\text { TOF-MS }\end{array}$ & 4 & 4 & $\begin{array}{l}214 \text { (7-14 } \\
\text { day), } 37 \\
(14-21 \text { day), } 0 \\
(21-28 \text { day) }\end{array}$ & $\begin{array}{l}\text { Vascular cell } \\
\text { adhesion protein } \\
\text { (V-CAM), GTP } \\
\text { binding protein } \\
\text { RAD, Collagen } \\
\text { alpha } 1 \text { (ii) chain } \\
\text { precursor and } \\
\text { Leukemia inhibitory } \\
\text { factor precursor LIF } \\
\text { Cholin are identified } \\
\text { in chondrogenesis. }\end{array}$ & 28) \\
\hline $\begin{array}{l}\text { hUC- } \\
\text { MSCs }\end{array}$ & NA & $\begin{array}{l}\text { P1, } \\
\text { spheroid } \\
\text { formation }\end{array}$ & $\begin{array}{l}1 \mathrm{ng} / \mathrm{mL} \\
\mathrm{hTGF}-\mathrm{b} 3 \\
4,7,14,28 \\
\text { and } 46 \text { days }\end{array}$ & $\begin{array}{l}\text { 2DE-DIGE/ } \\
\text { MALDI- } \\
\text { TOF/TOF }\end{array}$ & 54 & 39 & 94 & $\begin{array}{l}15 \text { identified } \\
\text { proteins were } \\
\text { down-regulated, } \\
21 \text { proteins were } \\
\text { up-regulated and } \\
3 \text { proteins were } \\
\text { highly modulated } \\
\text { during the process. }\end{array}$ & 23) \\
\hline pASCs & NA & $\begin{array}{l}\text { P3, PGA/ } \\
\text { PLA scaffold }\end{array}$ & $\begin{array}{l}10 \mathrm{ng} / \mathrm{mL} \\
\text { TGF-b1, } \\
3 \text { and } 6 \\
\text { months }\end{array}$ & $\begin{array}{l}\text { 2DE/ } \\
\text { MALDI- } \\
\text { TOF }\end{array}$ & 43 & 16 & 43 & $\begin{array}{l}\text { The first in vivo } \\
\text { proteomic study on } \\
\text { chondrogenesis. } \\
\text { Alpha-S1-casein } \\
\text { precursor, protein } \\
\text { disulfide-isomerase } \\
\text { A3 precursor, } \\
\text { dermcidin } \\
\text { precursor and } \\
\text { complement factor } \\
\text { D precursor with } \\
\text { unknown functions } \\
\text { were identified. }\end{array}$ & (34) \\
\hline
\end{tabular}




\begin{tabular}{|c|c|c|c|c|c|c|c|c|c|}
\hline \multirow{2}{*}{$\begin{array}{l}\text { Cell } \\
\text { type/ } \\
\text { source }\end{array}$} & \multirow[b]{2}{*}{ Cell Line } & \multirow{2}{*}{$\begin{array}{l}\text { Passage/ } \\
\text { Culture type }\end{array}$} & \multirow{2}{*}{$\begin{array}{l}\text { Treatment/ } \\
\text { Duration }\end{array}$} & \multirow{2}{*}{$\begin{array}{l}\text { Proteomic } \\
\text { approach }\end{array}$} & \multicolumn{2}{|c|}{$\begin{array}{l}\text { Identified } \\
\text { proteins }\end{array}$} & \multirow{2}{*}{$\begin{array}{l}\text { Differentially } \\
\text { expressed } \\
\text { proteins }\end{array}$} & \multirow[t]{2}{*}{ Major result } & \multirow[t]{2}{*}{ Ref. } \\
\hline & & & & & Total & Unique & & & \\
\hline mMSCs & ATDC5 & $\begin{array}{l}\text { P3, } \\
\text { pellet }\end{array}$ & $\begin{array}{l}10 \mathrm{ng} / \mathrm{mL} \\
\text { TGF-b3, }\end{array}$ & $\begin{array}{l}\text { MALDI- } \\
\text { TOF-MS }\end{array}$ & 246 & 5 & 15 & $\begin{array}{l}\text { Glycoproteomic } \\
\text { study.Levels of } \\
\text { high mannose } \\
\text { type N-glycans } \\
\text { increase during } \\
\text { chondrogenic } \\
\text { differentiation. } \\
\text { Aquaporin-1, } \\
\text { collagen alpha-1(III) } \\
\text { chain, collagen } \\
\text { alpha-1 (XI) chain, } \\
\text { ectonucleotide } \\
\text { pyrophosphatase/ } \\
\text { phosphodiesterase } \\
\text { family member } \\
1 \text { and netrin } \\
\text { receptor UNC5B } \\
\text { are proposed as } \\
\text { biomarkers. }\end{array}$ & 30) \\
\hline
\end{tabular}

Abbreviations: 2D, two-dimentional; 2-DE, two-dimensional gel electrophoresis; $\mathrm{PASC}$, porcine adipose derived stem cell; $\mathrm{BM}$, bone marrow; DIGE, difference in-gel electrophoresis; $\mathrm{mEMC}$, murine embryonic mesenchymal cell; $h B M$, human bone marrow; iTRAQ. Isobaric tag for relative and absolute quantitation; LC, liquid chromatography; MALDI, matrixassisted laser desorption/ionization;MS, mass spectrometry; MS/MS, tandem mass spectrometry; MSCs, mesenchymal stem cells; NA, not available; ND, not determined; rBM, rat bone marrow; SILAC, stable isotope labelling by amino acids in cell culture; TGF, transforming growth factor; TOF, time-of-flight; UC, umbilical cord.

Table 3: Identified Up-regulated Proteins Expression during Chondrogenesis.

\section{List of Proteins}

\section{ECM and Cytoskeleton related Protein}

Annexin A1, A2, A4, A5, A6, Actin-related protein 2/3 complex subunit 4, Actin-related protein 3, Aquaporin-1, Biglycan, Chondroadherin, Collagen alpha-1(III) chain, Collagen alpha-1(XI) chain, Collagen alpha-2(VI) chain, Collagen alpha-3(VI) chain, Ectonucleotide pyrophosphatase/ phosphodiesterase family member 1, Fibronectin, HSP, Netrin receptor UNC5B, Transgelin, Vimentin, Gelsolin, T-plastin, g-Actin, a-Cardiac actin, Collagen-binding protein 2, Tubulin beta chain, Tubulin beta-2C chain, Procollagen-lysine, Zyxin, Transforming growth factor-beta-induced protein ig-h3 precursor

\section{Metabolic Enzymes}

Aldose reductase, Alpha-enolase, ATP synthase subunit alpha, ATP synthase subunit beta, Carbonyl reductase, Dihydropyrimidinaserelated protein 2, Glyceraldehyde-3-phosphate dehydrogenase, Glycogen phosphorylase, L-Lactate alpha-glucosidase, NADPH dehydrogenase, Nicotinamide N-methyltransferase, Thioredoxin reductase, Malate dehydrogenase, Tyrosyl-tRNA synthetase,UDPglucose-6-dehydrogenase, Phosphoglycerate kinase 1, Phosphoglycerate mutase 1, Glucose-6-phosphate 1-dehydrogenase, Pyruvate kinase, M2 isozyme, Aldehyde dehydrogenase X, Sodium/potassium-transpoting ATPase subunit alpha-1, Transaldolase, Transketolase, Trisephosphate isomerise, a, b, g-Enolase

\section{Protein Synthesis and Degradation}

Aminipeptidase N, Cathepsin B, Cathepsin D, Elongation factor 1-gamma, Histone H2A type 1-C, Histone H4, T-complex protein 1, Ubiquitin carboxyl-terminal hydrolase isozyme L1, Proteasome subunit a type 2, Polymerase I and transcript release factor, TyrosyltRNA synthetase, Heterogeneous nuclear ribonucleoprotein D-like, ADAM Metallopeptidase Domain 15

\section{Chaperones and stress}

78 kDa glucose-regulated protein, Endoplasmin, Peroxiredoxin-6, Peptidyl-prolyl cis-trans isomerise A, Superoxide dismutase [Mn], Heat shock protein beta-1, Stress-induced phosphoprotein 1

\section{Others}

Caveolin-1, Dolichyl-diphosphooligosac charide-protein glycosyltransferase sub-unit 1, Lactadherin, Heat shock 27-kDa protein, Programmed cell death 6 interacting protein, Septin 6, Peroxiredoxin 2, Chloride intracellular channel protein 4, Nicotinamide $\mathrm{N}$-methyltransferase, Prelamin-A/C, Transforming growth factor-beta-induced protein ig-h3, Transmembrane emp24 domaincontaining protein 9 , Protein disulfide-isomerase A3 
Table 4: Identified Down-regulated Proteins Expression during Chondrogenesis.

\begin{tabular}{l} 
List of Proteins \\
ECM and Cytoskeleton related Protein \\
Caldesmon, Talin-1, Tropomyosin alpha-4 chain \\
Metabolic Enzymes \\
Phosphoglycerate mutase 1 \\
Protein Synthesis and Degradation \\
Elongation factor 1-delta, Glycyl-tRNA synthetase, Phosphoserine aminotrans-ferase, Poly(rC)-binding protein 1, Serine/ \\
threonine-protein phosphatase PP1-beta catalytic subunit, Reticulocalbin-1, \\
Chaperones and stress \\
Heat shock protein beta-1, Peptidyl-prolyl cis-trans isomerase A, Calumenin, Protein SET, Calreticulin, Peroxiredoxin-5, \\
Glutathione S-transferase P, GRP78, \\
Others \\
Perilipin-3, Sorting nexin-9, Cysteine and glycine-rich protein 1, SH3 domain-binding glutamic acid-rich-like protein 3, \\
Ferritin light chain, Protein disulfide-isomerase A1, Parathyroid hormone-related protein \\
\hline
\end{tabular}

\section{Challenges in Proteomic Study and Future Perspective}

A major challenge in proteomics is to obtain consistent results across all the studies of chondrogenesis. It remains difficult to draw definitive conclusions from individual studies as each study utilizes a different cell type, passages number, passaging method, chondrogenic differentiation method, and proteomic approach with MS, as the choice and the performance of MS are different in many of the studies. These factors should be taken into careful consideration for the future. Current studies focus only on evaluating the protein changes in the early differentiation process (8). There is no study which directly compares the protein expression and the differences between $\mathrm{CMSC}$ and $A C$. With the growing evidence that $c M S C$ is different from AC, more studies should be conducted to determine the cause of these differences.

\section{Concluding Remarks}

Proteomic approaches can generate large data sets of the proteins involved in the mechanisms and pathways of chondrogenesis. These studies will lead to a better understanding of chondrogenesis and the processes of its differentiation. Current reviews of research data are relatively preliminary, but the outcome data is still very interesting. Robust and rigorous studies in the future would allow for more definitive conclusions. In the near future, with the improvement in chemical-labelling reagents and MS performance, large-scale MS-based protein quantification approaches will become more economically possible and will significantly improve research on chondrogenesis that can lead to better outcome findings.

\section{Disclosure of Potential Conflicts of Interest}

The author indicates no potential conflicts of interest.

\section{References}

1. Buckwalter JA, Mankin HJ. Articular cartilage repair and transplantation. Arthritis Rheum. 1998; 41(8):1331-1342.

2. Koelling S, Kruegel J, Irmer M, et al. Migratory chondrogenic progenitor cells from repair tissue during the later stages of human osteoarthritis. Cell Stem Cell. 2009; 4(4):324-335.

3. Ahmed TA, Giulivi A, Griffith $M$, et al. Fibrin glues in combination with mesenchymal stem cells to develop a tissue-engineered cartilage substitute. Tissue Eng Part A. 2011; 17(3-4):323-335.

4. Dashtdar $\mathrm{H}$, Rothan $\mathrm{HA}$, Tay $\mathrm{T}$, et al. A preliminary study comparing the use of allogenic chondrogenic pre-differentiated and undifferentiated mesenchymal stem cells for the repair of full thickness articular cartilage defects in rabbits. J Orthop Res. 2011; 29(9):1336-1342.

5. Tay LX, Ahmad RE, Dashtdar H, et al. Treatment outcomes of alginate-embedded allogenic mesenchymal stem cells versus autologous chondrocytes for the repair of focal articular cartilage 
defects in a rabbit model. Am J Sports Med. 2011; 40(1):83-90.

6. Chiang $\mathrm{H}$, Hsieh $\mathrm{CH}$, Lin $\mathrm{YH}$, et al. Differences between chondrocytes and bone marrow-derived chondrogenic cells. Tissue Eng Part A. 2011; 17(2324):2919-2929.

7. Gleghorn JP, Jones AR, Flannery CR, et al. Boundary mode frictional properties of engineered cartilaginous tissues. Eur Cell Mater 2007; 14:20-28; discussion 2829.

8. Huang $A H$, Stein A, Mauck RL. Evaluation of the complex transcriptional topography of mesenchymal stem cell chondrogenesis for cartilage tissue engineering. Tissue Eng Part A. 2010; 16(9):26992708.

9. Karlsson C, Brantsing C, Svensson T, et al. Differentiation of human mesenchymal stem cells and articular chondrocytes: analysis of chondrogenic potential and expression pattern of differentiationrelated transcription factors. J Orthop Res. 2007; 25(2):152-163.

10. Kim J, Shin JM, Jeon YJ, et al. Proteomic validation of multifunctional molecules in mesenchymal stem cells derived from human bone marrow, umbilical cord blood and peripheral blood. PLoS One. 2012; 7(5):e32350.

11. Park HW, Shin JS, Kim CW. Proteome of mesenchymal stem cells. Proteomics. 2007; 7(16):2881-2894.

12. Roche S, Provansal M, Tiers L, et al. Proteomics of primary mesenchymal stem cells. Regen Med. 2006; 1(4):511-517.

13. Barry F, Boynton RE, Liu B, et al. Chondrogenic differentiation of mesenchymal stem cells from bone marrow: differentiation-dependent gene expression of matrix components. Exp Cell Res. 2001; 268(2):189-200.

14. DeLise AM, Fischer L, Tuan RS. Cellular interactions and signaling in cartilage development. Osteoarthritis Cartilage. 2000; 8(5):309-334.

15. Hellingman CA, Koevoet W, Kops N, et al. Fibroblast growth factor receptors in in vitro and in vivo chondrogenesis: relating tissue engineering using adult mesenchymal stem cells to embryonic development. Tissue Eng Part A. 2011; 16(2):545-556.

16. Herlofsen SR, Kuchler AM, Melvik JE, et al. Chondrogenic differentiation of human bone marrow-derived mesenchymal stem cells in selfgelling alginate discs reveals novel chondrogenic signature gene clusters. Tissue Eng Part A. 2011; 17(7-8):1003-1013.

17. Xu J, Wang W, Ludeman $M$, et al. Chondrogenic differentiation of human mesenchymal stem cells in three-dimensional alginate gels. Tissue Eng Part $A$. 2008; 14(5):667-680.

18. Hao J, Varshney RR, Wang DA. TGF-beta3: A promising growth factor in engineered organogenesis. Expert Opin Biol Ther. 2008; 8(10):1485-1493.

19. Heng BC, Cao T, Lee EH. Directing stem cell differentiation into the chondrogenic lineage in vitro. Stem Cells. 2004; 22(7):1152-1167.
20. Karlsen TA, Shahdadfar A, Brinchmann JE. Human primary articular chondrocytes, chondroblasts-like cells, and dedifferentiated chondrocytes: differences in gene, microRNA, and protein expression and phenotype. Tissue Eng Part C Methods. 2011; 17(2):219-227.

21. Adachi N, Ochi M, Deie $M$, et al. Transplant of mesenchymal stem cells and hydroxyapatite ceramics to treat severe osteochondral damage after septic arthritis of the knee. J Rheumatol. 2005; 32(8):16151618.

22. Wakitani S, Yamamoto T. Response of the donor and recipient cells in mesenchymal cell transplantation to cartilage defect. Microsc Res Tech. 2002; 58(1):14-18.

23. De la Fuente A, Mateos J, Lesende-Rodriguez I, et al. Proteome analysis during chondrocyte differentiation in a new chondrogenesis model using human umbilical cord stroma mesenchymal stem cells. $\mathrm{Mol}$ Cell Proteomics. 2011; 11(2):M111 010496.

24. Ji YH, Ji JL, Sun FY, et al. Quantitative proteomics analysis of chondrogenic differentiation of C3H10T1/2 mesenchymal stem cells by iTRAQ labeling coupled with on-line two-dimensional LC/MS/MS. Mol Cell Proteomics. 2010; 9(3):550-564.

25. Pandey A, Mann M. Proteomics to study genes and genomes. Nature. 2000; 405(6788):837-846.

26. Matt $\mathrm{P}, \mathrm{Fu} \mathrm{Z}, \mathrm{Fu} \mathrm{Q}$, et al. Biomarker discovery: proteome fractionation and separation in biological samples. Physiol Genomics. 2008; 33(1):12-17.

27. Wang D, Park JS, Chu JS, et al. Proteomic profiling of bone marrow mesenchymal stem cells upon transforming growth factor beta1 stimulation. J Biol Chem. 2004; 279(42):43725-43734.

28. Celebi B, Elcin AE, Elcin YM. Proteome analysis of rat bone marrow mesenchymal stem cell differentiation. J Proteome Res. 2010; 9(10):5217-5227.

29. Rocha B, Calamia V, Mateos J, et al. Metabolic labeling of human bone marrow mesenchymal stem cells for the quantitative analysis of their chondrogenic differentiation. J Proteome Res. 2012; 11(11):53505361.

30. Ishihara T, Kakiya K, Takahashi K, et al. Discovery of novel differentiation markers in the early stage of chondrogenesis by glycoform-focused reverse proteomics and genomics. Biochim Biophys Acta. Oct 242013.

31. Cordwell SJ, Thingholm TE. Technologies for plasma membrane proteomics. Proteomics. 2010; 10(4):611627.

32. Pabst $\mathrm{M}, \mathrm{Wu} \mathrm{SQ}, \mathrm{Grass}$ J, et al. IL-1beta and TNF-alpha alter the glycophenotype of primary human chondrocytes in vitro. Carbohydr Res. 2010; 345(10):1389-1393.

33. Toegel S, Pabst M, Wu SQ, et al. Phenotype-related differential alpha-2,6- or alpha-2,3-sialylation of glycoprotein $\mathrm{N}$-glycans in human chondrocytes. Osteoarthritis Cartilage. 2010; 18(2):240-248.

34. Gong L, Zhou X, Wu Y, et al. Proteomic Analysis Profile of Engineered Articular Cartilage with Chondrogenic 
Differentiated Adipose Tissue-Derived Stem Cells Loaded Polyglycolic Acid Mesh for Weight-Bearing Area Defect Repair. Tissue Eng Part A. Nov 142013.

35. Gevaert K, Vandekerckhove J. Protein identification methods in proteomics. Electrophoresis. 2000; 21(6):1145-1154.
36. Lopez JL. Two-dimensional electrophoresis in proteome expression analysis. J Chromatogr B Analyt Technol Biomed Life Sci. 2007; 849(1-2):190-202.

37. Vercauteren FG, Arckens L, Quirion R. Applications and current challenges of proteomic approaches, focusing on two-dimensional electrophoresis. Amino Acids. 2007; 33(3):405-414. 